\title{
Biological activity of composts obtained from hop waste generated during the brewing
}

\author{
Michał Kopeć ${ }^{1}$ (D) $\cdot$ Monika Mierzwa-Hersztek ${ }^{1,4}$ (D) Krzysztof Gondek $^{1}$ (D) $\cdot$ Katarzyna Wolny- \\ Koładka $^{2}$ (I) $\cdot$ Marek Zdaniewicz $^{3}$ (I) $\cdot$ Renata Jarosz $^{4}$ (D)
}

Received: 14 March 2020 / Revised: 24 April 2020 / Accepted: 29 April 2020 / Published online: 15 May 2020

(C) The Author(s) 2020

\begin{abstract}
New ways of managing hop sediments from brewing and fermentation of beer are constantly being sought and the existing ones improved as part of the circular economy. These wastes are not generated in large amounts, but the absence of their proper characteristics may lead to further processing errors. The study analyses the composting of hop waste under laboratory conditions and the effects of the biological activity of composts introduced into the soil. The study was carried out on two-hop sediments from two different technological stages of beer production: hot trub (HT) and spent hops (SH). Chemical, microbiological and biochemical analyses, as well as the assessment of phytotoxicity to Lepidium sativum L., were performed in the materials. The results proved that, due to their formation technology, the tested feedstocks are safe from an epidemiological point of view and are not a source of microbial contamination. Inhibitory properties for plant development were found for HT and it most likely results from the organic compound content. The mineral composition of hot trub does not exclude composting if its share in biomass is low. Spent hops (SH) were characterised by a significant total nitrogen content, which affected the composting process. Composting this sediment required the selection of substrates with a wide $\mathrm{C}: \mathrm{N}$ ratio. The number of microorganisms inhabiting the analysed material was very diverse and varied depending on the type of sediments. The sample that contained the composted SH from dry hopping had a much larger number of microorganisms than the sample with HT from wet hopping.
\end{abstract}

Keywords Compost $\cdot$ Brewing $\cdot$ Hop sediments $\cdot$ Biological activity of composts

\section{Introduction}

Apart from spent grains (brewers' grains), beer production generates two types of solid waste associated with the hops

Monika Mierzwa-Hersztek

monika6_mierzwa@wp.pl; monika.mierzwa@urk.edu.pl

1 Department of Agricultural and Environmental Chemistry, University of Agriculture of Krakow, al. Mickiewicza 21, 31-120, Krakow, Poland

2 Department of Microbiology and Biomonitoring, University of Agriculture of Krakow, al. Mickiewicza 24/28, 30-059, Krakow, Poland

3 Department of Fermentation Technology and Microbiology, University of Agriculture of Krakow, ul. Balicka 122, 30-149 Kraków, Poland

4 Department of Mineralogy, Petrography and Geochemistry, AGH University of Science and Technology, al. Mickiewicza 30, 30-059 Kraków, Poland used. These are hot trub and spent hops resulting from dry hopping [1-5]. The estimated amount of spent gains is 17.6 $\mathrm{kg} / \mathrm{hl}$ of product [6]. The amount of filtration sediments in the brewing industry (waste code 020780 ) is from 0.55 to $2.61 \mathrm{~kg}$ / $\mathrm{hl}$ of beer, with an average of $1.22 \mathrm{~kg} / \mathrm{hl}$ [6]. According to Sterczyńska et al. [5], $1 \mathrm{~m}^{3}$ of ready beer generates $51.2 \mathrm{~kg}$ of solid waste, including filtration sediments. This value is much smaller than the one published 10 years ago [6]. The amount of generated waste is not large, but taking into account the scale of beer consumption, there is the possibility of local environmental and economic problems [4, 7-9].

Hop is a specific plant that is introduced into the process to achieve the specific flavour and preservative values. A very strong, specific aroma and a rather bitter taste are achieved thanks to lupulin obtained from common hop cones. These substances also show selective and weak bactericidal and bacteriostatic activity against Gram-positive and Gram-negative bacteria [10-12]. The methods of hop application in the brewing process, based on granules or extracts, affect the amount of filtration sediments and their characteristics. 
According to Fărcaș et al. [8], only $15 \%$ of hop ingredients comes to beer, and $85 \%$ of them remain in hop sediments. Despite brewing, traditional hop granules retain many active compounds in brewing sediments; however, the nature of these compounds is still hygienising. Bedini et al. [13] argued that the high content of essential oils (sesquiterpenes in most) promotes the use of this waste (low cost of feedstock) for the production of an ecological alternative to synthetic repellents in the protection of stored food against insects. This is due to the fact that a number of identified substances in this type of waste are classified as semiochemicals.

Because of their low amounts, hop sediments were usually mixed with spent grains. However, the specificity of managing by-products and waste from brewery requires their indepth characterisation. Hop sediments from the brewery are used on a small scale. The bitter compounds present in waste containing hops prevent their application as feed [9]; however, Flythe and Alken [10] proved that fermentation can be enhanced in the rumen. Fărcaş et al. [8] claimed that, due to the presence of 2-methyl-3-buten-2-ol, these wastes proved to be inapplicable as a feed additive. The literature indicates their possible use in animal nutrition, but only as a $1-2 \%$ addition in relation to the mass of brewers grains [6].

Nowadays, attention is focused on the possibilities of using or managing hop sediments in medicine and cosmetology, which results from the presence of specific organic compounds [4, 6, 9]. Hop extracts or oils obtained from hop cones can be successfully used in medicine as a sedative and, due to their antioxidant and antimicrobial effects, for the production of cosmetics [14].

However, the least problematic seems to be the recovery in the process of aerobic treatment of this waste [7]. Composting based on changes in organic matter gives an environmentally safe product. Recognition of the chemical composition and biological activity of hop waste allows controlling composting and selecting substrates to optimise the process. This is even more important, because, as stated by Flythe et al. [11], hop extracts have an inhibitory effect on the methanogenesis process and thus limit the possibility of anaerobic decomposition of such waste.

The aim of the study was to assess the effect of hop sediments from beer brewing on the properties of compost obtained from them and under soil incubation conditions. The study adopted a condition that the quality and value of composts are affected by the type of hop sediment applied.

\section{Material and methods}

\subsection{Feedstocks and composts}

The study was conducted on samples of hop sediments collected in an industrial brewery downstream of the technological process. The first sediment analysed was hot trub (HT) and the second spent hops ( $\mathrm{SH})$.

Hot trub was formed during wort boiling with Polish varieties of hop under industrial conditions. It was collected from the whirlpool tank after wort boiling with hops. The wort was boiled for $90 \mathrm{~min}$ and hops were added to the wort in 3 doses: the first in the 15 th minute, after reaching $98^{\circ} \mathrm{C}$, the second in the 75th minute and the third directly to the whirlpool tank where the whole mixture was kept for $20 \mathrm{~min}$ to stabilise the cone of hot sediments.

Spent hops were obtained after dry hopping of beer with Polish hop varieties under industrial conditions. Spent hops were collected from a maturation tank in which the beer was dry hopped at approx. $3{ }^{\circ} \mathrm{C}$ for nearly $72 \mathrm{~h}$.

Hop sediments were analysed for chemical and microbiological composition [15]. During the study on the characteristics and suitability of hop sediments for biological transformation, the authors focused on composts. The products formed during the composting process were tested under soil incubation conditions to verify their suitability in the environment.

Composting was carried out for 90 days under controlled conditions. The experiment consisted of 3 treatments carried out in 3 replications: I, control treatment - C (maize straw); II, maize straw $(\mathrm{C})+$ hot trub $(\mathrm{HT})$; III, maize straw $(\mathrm{C})+$ spent hops $(\mathrm{SH})$ and composts were marked as follows: $\mathrm{cC}, \mathrm{c}(\mathrm{C}+$ $\mathrm{HT}), \mathrm{c}(\mathrm{C}+\mathrm{SH})$. Hop sediments obtained from beer production were mixed with maize straw in a 1:1 ratio calculated on a dry matter to obtain $2 \mathrm{~kg}$ of fresh mass. The maize substrate was selected because of the correct chemical composition for the process and the optimal $\mathrm{C}: \mathrm{N}$ ratio. The addition of sediments modified this parameter. A typical temperature regime for the composting process was established. The containers with the material were placed in a water bath, while maintaining the following temperature regime: the first 10 days: $-60{ }^{\circ} \mathrm{C}$; 11th-30th day: $-50{ }^{\circ} \mathrm{C}$ and then until 90th day: $-30{ }^{\circ} \mathrm{C}$. Samples were taken three times every 30 days during the composting period. After 30,60 and 90 days, the material was dried and analysed. During the process, the material was aerated automatically in 8 cycles a day, every $3 \mathrm{~h}$ for $15 \mathrm{~min}$ (with a capacity of $600 \mathrm{l} / \mathrm{h}$ ) and manually every other day. In the first half of the experiment, material moisture was maintained at $65 \%$, and then, the material was allowed to evaporate to $40 \%$.

In order to obtain information in a full cycle, the composts were incubated with soil (S). The soil before incubation had $\mathrm{pH}$ of 4.48 in $\mathrm{H}_{2} \mathrm{O}$ and 4.10 in $\mathrm{KCl}, \mathrm{N}$ content of $2.75 \mathrm{~g} / \mathrm{kg}, \mathrm{C}$ content of $26.56 \mathrm{~g} / \mathrm{kg}(\mathrm{C}: \mathrm{N}=9.66), \mathrm{Hh}=130.9 \mathrm{mmol}(+) / \mathrm{kg}$, $\mathrm{S}=120.7 \mathrm{mmol}(+) / \mathrm{kg}$ and $\mathrm{V}=47.8 \%$. The granulometric composition included the fractions of sand $(1-0.1 \mathrm{~mm})=$ $17 \%$, dust $(0.01-0.02 \mathrm{~mm})=31 \%$ and loam (below 0.02 $\mathrm{mm})=52 \%$. Composts in provocative amounts were introduced into the soil while maintaining a dry matter ratio of 10:1 (soil:compost), and the following four variants were obtained: $\mathrm{S}, \mathrm{S}+\mathrm{cC}, \mathrm{S}+\mathrm{c}(\mathrm{C}+\mathrm{HT}), \mathrm{S}+\mathrm{c}(\mathrm{C}+\mathrm{SH})$. The material prepared in 
this way was incubated (30 days) at a constant temperature of $25{ }^{\circ} \mathrm{C}$ in $2.5 \mathrm{dm}^{3}$ vessels in which air was periodically exchanged.

\subsection{Chemical analyses}

After composting, material samples were collected and the dry matter content was determined in them by the weight method after drying the sample at $105{ }^{\circ} \mathrm{C}$ for $24 \mathrm{~h}$. To determine the chemical composition, samples of starting materials and composts were ashed in a chamber furnace at $450{ }^{\circ} \mathrm{C}$ for $12 \mathrm{~h}$. Once the ash was digested in diluted (1:2) $\mathrm{HNO}_{3}$, the samples were transferred to flasks and the final sample volume was adjusted to $50 \mathrm{ml}$ by adding redistilled water. The tested element contents in the obtained solutions were determined by the ICP-OES method. In the suspension of compost in water (1:10 ratio), the $\mathrm{pH}$ was determined potentiometrically ( $\mathrm{pH}-$ metre CP-505, Elmentron, Zabrze, Poland) and electrical conductivity (EC) using the conductometer CCO-501 (Elmentron, Zabrze, Poland). The total carbon and nitrogen contents were determined on a Vario MAX Cube analyser with an IR sensor (Vario MAX Cube, Elementar Analysensysteme, GmbH, Germany).

\subsection{Respiratory activity}

Respiratory activity (the effect of $\mathrm{CO}_{2}$ changes in the volume of the closed vessel) of composted materials and the 30-day effect of incubation of composts with soil were determined by the manometric method, using OxiTop measuring apparatus, in accordance with ISO 148551:2005 (Fig. 1). Samples used in the study had $40 \mathrm{~g}$ of fresh mass.

The manometric measurement of respiratory activity of the studied materials involved the recording of pressure changes in closed containers in a continuous system (pic. 1). Pressure changes are proportional to the amount of oxygen consumed by the sample as a result of respiratory processes occurring in it (OxiTop® 2003). Measuring time for respiratory activity was different for each material (including the lag-faze period to stabilise conditions and the period of actual measurements of respiratory activity). Pressure changes were recorded automatically every $30 \mathrm{~min}$. The resulting equivalent quantities of $\mathrm{CO}_{2}$ were absorbed by $1 \mathrm{~mol} / \mathrm{dm} \mathrm{NaOH}$ present in the vessels. The system used for measuring respiratory activity consisted of measuring bottles with accessories. For the time of determination, measuring bottles were put into a thermostatic cabinet, providing a constant temperature of $25.0^{\circ} \mathrm{C}\left( \pm 0.1{ }^{\circ} \mathrm{C}\right)$. Measurement data were sent to the controller through an infrared interface and, then, to the computer using Achat OC. Respiratory activity of materials was converted into the dry matter by the following formula:

$R A=\frac{M O_{2}}{R \cdot T} \cdot \frac{V_{f r}}{m_{B t}} \cdot|\Delta p|\left[m g O_{2} /(g \cdot h)\right]$

where RA is the respiratory activity; $\mathrm{MO}_{2}$ is the oxygen molecular weight $(31998 \mathrm{mg} / \mathrm{mol}) ; R$ is the general gas constant $(83.14 \mathrm{~L} / \mathrm{hPa} /(\mathrm{K} / \mathrm{mol}) ; T$ is the measurement temperature $(K)$; $\mathrm{mBt}$ is the dry mass weight in the composted material $(\mathrm{kg})$; $|\Delta \mathrm{p}|$ is the pressure change (hPa) and Vfr is the free gas volume.

The analysis of garden cress (Lepidium sativum L.) growth in contact with compost extract was made after obtaining extracts (material:water ratio of 1:10,24-h extraction) in a closed vessel with carbon dioxide absorption and manometric measurement (OxiTop) [16]. The extract was $0.45 \mu \mathrm{m}$ filtered using a vacuum pump. The control treatment was in a vessel in which the seedling growth test was conducted only against redistilled water. A mass of $0.268 \mathrm{~g}$ seeds, corresponding to 100 Lepidium sativum L. seeds, was used for the analysis. The test was carried out for 4 days. The result of the seeding
Fig. 1 OxiTop® control measuring set for respiratory activity

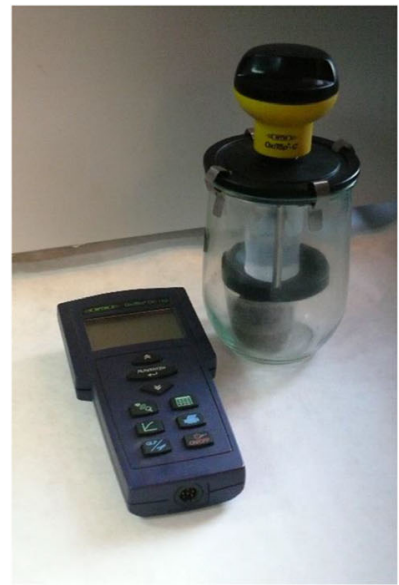


growth test was calculated using the formula (1) and presented in the form of regression equations of oxygen consumption $48 \mathrm{~h}$ after the addition of extract of sediments and expressed in $\mathrm{O}_{2} \cdot(\mathrm{g} \cdot \mathrm{h})^{-1}$.

\subsection{Microbiocenotic composition}

After incubation using the serial dilution method developed by Koch with a number of microbiological substrates, the following groups of microorganisms were determined: vegetative and endospore bacteria (Trypticasein Soy Lab Agar, BTL, Poland, grown at $37{ }^{\circ} \mathrm{C}$ for $24 \mathrm{~h}$ ), mould fungi (Malt Extract Agar, BTL, Poland, grown at $28{ }^{\circ} \mathrm{C}$ for 5 days) and Actinomycetes (Actinomycete Isolation Lab Agar, Biocorp, Poland, grown at $28{ }^{\circ} \mathrm{C}$ for 7 days). The tube method was used to determine the titres of microorganisms participating in the transformations of nitrogen: nitrifiers (Winogradsky medium, grown at $28{ }^{\circ} \mathrm{C}$ for 7 days, denitrifiers (Giltaya medium, grown at $28^{\circ} \mathrm{C}$ for 7 days), Clostridium pasteurianum (Rougieux medium, grown at $28^{\circ} \mathrm{C}$ for 7 days) [17] and the number of colony-forming units for Azotobacter spp. (Ashby agar [18], grown at $28{ }^{\circ} \mathrm{C}$ for 7 days) and for ammonifiers (Rougieux medium, grown at $28{ }^{\circ} \mathrm{C}$ for 7 days) [17]. Potentially pathogenic bacteria were also determined: Staphylococcus spp. (MSA agar, BTL Poland, grown at 37 ${ }^{\circ} \mathrm{C}$ for $24 \mathrm{~h}$ ), Escherichia coli (TBX agar, BTL Poland, grown at $44^{\circ} \mathrm{C}$ for $24 \mathrm{~h}$ ), Salmonella spp. and Shigella spp. (SS agar, BTL Poland, grown at $37^{\circ} \mathrm{C}$ for $24 \mathrm{~h}$ ), Enterococcus faecalis (SB agar, BTL Poland, grown at $37{ }^{\circ} \mathrm{C}$ for $48 \mathrm{~h}$ ) and Clostridium perfringens (SC agar, BTL Poland, grown at 37 ${ }^{\circ} \mathrm{C}$ for $24 \mathrm{~h}$ ), whose presence may pose a threat from an epidemiological point of view and is an important signal informing about microbial contamination $[19,20]$. The number of colony-forming units (CFU) of microorganisms was determined by the dilution culture method. The result was converted into $1 \mathrm{~g} \mathrm{DM}$ of soil or titre was determined for microorganisms participating in nitrification and denitrification processes [17].

\subsection{Statistical analyses}

The results of chemical and biochemical analyses were compiled statistically by presenting the arithmetic mean of replicates and standard deviation or using variance analysis and by synthesis using Tukey's test at a significance level of $p \leq 0.05$. The Shapiro-Wilk test was used to test the normality of the distribution when analysing variance.

\section{Results and discussion}

The content of macro- and microelements in beer wort is variable. It depends on the type, quality and quantity of feedstocks used [4]. Also, the chemical composition of the resulting filtration waste varies depending on the feedstocks used, brewing time and $\mathrm{pH}$ of the environment. Waste is very hydrated $(85 \%$ of it is water) and contains on average $50 \%$ of carbon, $8 \%$ of nitrogen and $2-5 \%$ ash in a dry matter $[4,15,21]$.

In our study, during composting of hop sediments, there were primarily changes in the carbon-nitrogen ratio in the organic material (Table 1). As a result of composting, the nitrogen was concentrated due to carbon loss. The largest changes took place for maize composting $(\mathrm{cC})$. The correct $\mathrm{C}: \mathrm{N}$ ratio was not achieved for the adopted maize:hop sediments ratio in the mixtures used for composting and it was lower than 30. Due to the high nitrogen content in sediments, the $\mathrm{C}: \mathrm{N}$ ratio was reduced to 15.6 for $\mathrm{c}(\mathrm{C}+\mathrm{SH})$ and to 27.9 for $\mathrm{c}(\mathrm{C}+\mathrm{HT})$, and these values were not assumed to be correct for the composting process. Composting of hop sediments, which are rich in nitrogen, requires the use of structural material with a much higher C:N ratio, e.g. straw and sawdust. During composting, the $\mathrm{C}: \mathrm{N}$ ratio decreased significantly in all treatments compared with the starting material. Our other study [15] revealed that the largest reduction of the $\mathrm{C}: \mathrm{N}$ ratio took place in the first composting period (up to the 30th day). Subsequent changes were not statistically significant in all treatments.

The addition of hop sediments to maize straw in the composting process increased the content of some elements, while some others were diluted. It also depended on the type of hop sediments. The contents of $\mathrm{Na}, \mathrm{Cd}, \mathrm{Cr}$, $\mathrm{Fe}, \mathrm{Mn}, \mathrm{Ni}$ and $\mathrm{Pb}$ were diluted irrespective of the sediment type used. The addition of HT enriched the compost in $\mathrm{K}$, whereas the addition of $\mathrm{SH}$ increased the content of total $\mathrm{Mg}, \mathrm{Ca}, \mathrm{P}$ and $\mathrm{Zn}$. For instance, the increased content of $\mathrm{Zn}$ in $\mathrm{c}(\mathrm{C}+\mathrm{SH})$ resulted from enriching the wort in $\mathrm{Zn}$ to assist fermentation [22].

Hot trub (HT) is a product obtained from wort boiling, which includes insoluble hop materials, such as products of hop polyphenols and wort proteins, as well as isomerised hop acids adsorbed on a solid fraction [8]. The composition of HT is important for further transformation of this waste. The compounds present in this material can buffer the extracted components in different ways, as shown by sequential extraction. In our study, noteworthy is the smaller share of $\mathrm{K}$ and, generally, the larger share of other elements, mainly $\mathrm{Na}, \mathrm{P}$ or $\mathrm{Zn}$ in the hop sediment compost extract than in maize compost extract (Table 2).

After 90 days of composting, a phytotoxicity test was carried out on 1:10 compost extraction solutions (Fig. 2). The test plant - cress - was maintained under OxiTop conditions for 7 days. After eliminating the germination period (lag phase), the equations of seedlings intensive transpiration (rectilinear trend lines $R>0.988$ from the 4th day) in contact with the solution had the following form and value for $x=96 \mathrm{~h}$ (corresponds to AT4): 
Table 1 Nitrogen and carbon contents $(\mathrm{g} / \mathrm{kg}$ ) and relative changes in dry matter residues during composting (on start day and after 90 days)

\begin{tabular}{|c|c|c|c|c|c|c|c|}
\hline \multirow[t]{3}{*}{ Parameter } & \multirow[t]{3}{*}{ SW test* } & \multicolumn{6}{|c|}{ Treatment } \\
\hline & & \multicolumn{6}{|l|}{ Days } \\
\hline & & 0 & 90 & 0 & 90 & 0 & 90 \\
\hline $\mathrm{Ng} / \mathrm{kg}$ & $0.942(p=0.313)$ & $10.5 * * \mathrm{a}$ & $37.6 \mathrm{~d}$ & $18.4 \mathrm{~b}$ & $33.8 \mathrm{c}$ & $30.4 \mathrm{c}$ & $52.0 \mathrm{e}$ \\
\hline $\mathrm{Cg} / \mathrm{kg}$ & $0.930(p=0.200)$ & $429.8 b$ & $386.3 \mathrm{a}$ & $513.8 \mathrm{~d}$ & $482.6 \mathrm{c}$ & $475.3 \mathrm{c}$ & $434.9 \mathrm{~b}$ \\
\hline $\mathrm{C}: \mathrm{N}$ & $0.867(p=0.116)$ & $40.9 \mathrm{a}$ & $10.3 \mathrm{~d}$ & $27.9 \mathrm{~b}$ & $14.3 \mathrm{c}$ & $15.6 \mathrm{c}$ & $8.4 \mathrm{~d}$ \\
\hline Relative changes in dry matter residues $(\%)^{* * *}$ & & 100 & 22.77 & 100 & 53.62 & 100 & 40.65 \\
\hline
\end{tabular}

*The Shapiro-Wilk test

$* *$ The different letters within a column indicate a significant difference at $p \leq 0.05$ according to Tukey's HSD test; time $\times$ material

****Relative to starting material during the composting process

$$
\begin{aligned}
& \mathrm{y}\left(\mathrm{H}_{2} \mathrm{O}\right) \quad \mathrm{y}=0.351 \mathrm{x}+15.87 \text { for } \mathrm{x}=96 \mathrm{~h} \mathrm{y} \\
& =49.5 \mathrm{mg} \mathrm{O}_{2} / \mathrm{g} \mathrm{DM} \\
& y(c C) \quad y=0.386 x+4.26 \text { for } x=96 h y \\
& =41.3 \mathrm{mg} \mathrm{O} / \mathrm{DM} \text {, } \\
& \text { y } \quad c(C+H T) \quad y=0.362 x-4.09 \quad \text { for } x=96 h y \\
& =30.6 \mathrm{mg} \mathrm{O} / \mathrm{DM} \text {, } \\
& \text { y } \quad c(C+S H) \quad y=0.549 x-12.18 \text { for } x=96 h y \\
& =40.5 \mathrm{mg} \mathrm{O} / \mathrm{DM} \text {. }
\end{aligned}
$$

The test showed that, in the initial period, the greatest oxygen consumption occurred in contact with water. It was confirmed in the mathematical model by the free expression of the equation. However, the analysis of equations from the 4th day (after $72 \mathrm{~h}$ ), including the direction coefficient, proved that the highest activity of germinating seeds of garden cress was in the extract with SH-based compost, and the smallest, similar to the treatment with water, in HT-based composts and in the control treatment. Positive responses for geranium and tomato

\begin{tabular}{|c|c|c|c|c|c|c|c|c|c|c|}
\hline \multirow[t]{2}{*}{ Parameter } & \multirow[t]{2}{*}{ Unit } & \multicolumn{3}{|c|}{ Total form } & \multicolumn{3}{|c|}{$\begin{array}{l}\text { Extract } \\
\text { 1:10 (compost:water) }\end{array}$} & \multicolumn{3}{|c|}{ Share of extract forms in total form $(\%)$} \\
\hline & & $\mathrm{cC}$ & $\mathrm{c}(\mathrm{C}+\mathrm{HT})$ & $\mathrm{c}(\mathrm{C}+\mathrm{SH})$ & $\mathrm{cC}$ & $\mathrm{c}(\mathrm{C}+\mathrm{HT})$ & $\mathrm{c}(\mathrm{C}+\mathrm{SH})$ & $\mathrm{cC}$ & $\mathrm{c}(\mathrm{C}+\mathrm{HT})$ & $\mathrm{c}(\mathrm{C}+\mathrm{SH})$ \\
\hline $\mathrm{pH}$ & - & & & & 8.96 & 7.61 & 7.74 & & & \\
\hline $\mathrm{EC}$ & $\mathrm{mS} / \mathrm{cm}$ & & & & 9.51 & 5.38 & 8.91 & & & \\
\hline $\mathrm{Na}$ & $\mathrm{mg} / \mathrm{kg}$ & 1087 & 455 & 491 & 301.8 & 196.3 & 247.2 & 27.8 & 43.1 & 50.3 \\
\hline K & $\mathrm{mg} / \mathrm{kg}$ & 26315 & 28778 & 26962 & 17480 & 13490 & 14660 & 66.4 & 46.9 & 54.4 \\
\hline $\mathrm{Mg}$ & $\mathrm{mg} / \mathrm{kg}$ & 6931 & 5769 & 9426 & 437.2 & 365.6 & 470.7 & 6.3 & 6.3 & 5.0 \\
\hline $\mathrm{Ca}$ & $\mathrm{mg} / \mathrm{kg}$ & 20127 & 20345 & 24369 & 566 & 705 & 1212 & 2.8 & 3.5 & 5.0 \\
\hline $\mathrm{P}$ & $\mathrm{mg} / \mathrm{kg}$ & 16330 & 9903 & 21355 & 2069 & 2287 & 4879 & 12.7 & 23.1 & 22.8 \\
\hline $\mathrm{Cd}$ & $\mathrm{mg} / \mathrm{kg}$ & 1.091 & 0.308 & 0.503 & 0.87 & 0.24 & 0.33 & 79.7 & 77.9 & 65.6 \\
\hline $\mathrm{Cr}$ & $\mathrm{mg} / \mathrm{kg}$ & 8.226 & 3.715 & 4.613 & 0.25 & 0.17 & 0.27 & 3.0 & 4.6 & 5.9 \\
\hline $\mathrm{Fe}$ & $\mathrm{mg} / \mathrm{kg}$ & 1348 & 936 & 971 & 31.06 & 25.06 & 27.16 & 2.3 & 2.7 & 2.8 \\
\hline $\mathrm{Mn}$ & $\mathrm{mg} / \mathrm{kg}$ & 190 & 112 & 144 & 2.29 & 2.83 & 5.75 & 1.2 & 2.5 & 4.0 \\
\hline $\mathrm{Ni}$ & $\mathrm{mg} / \mathrm{kg}$ & 7.263 & 3.554 & 3.729 & 0.56 & 0.51 & 0.45 & 7.7 & 14.4 & 12.1 \\
\hline $\mathrm{Pb}$ & $\mathrm{mg} / \mathrm{kg}$ & 11.29 & 4.98 & 4.46 & 0.25 & 0.48 & 0.30 & 2.2 & 9.6 & 6.7 \\
\hline $\mathrm{Zn}$ & $\mathrm{mg} / \mathrm{kg}$ & 368 & 159 & 515 & 10.41 & 11.92 & 31.50 & 2.8 & 7.5 & 6.1 \\
\hline
\end{tabular}
biomass after applying composts based on brewing sludge were obtained by [7].

The soil response (respiratory activity) after compost application is shown in Fig. 3. Acidic soil (S) showed no need for oxygen, while the addition of composts stimulated microbial reactions whose models in three incubation periods are shown

Table 2 Mineral composition of composts as well as pH and EC in extracts 
Fig. 2 Cumulative effect of respiration of garden cress seeds and seedlings on compost extracts during 7 days of growth incubation

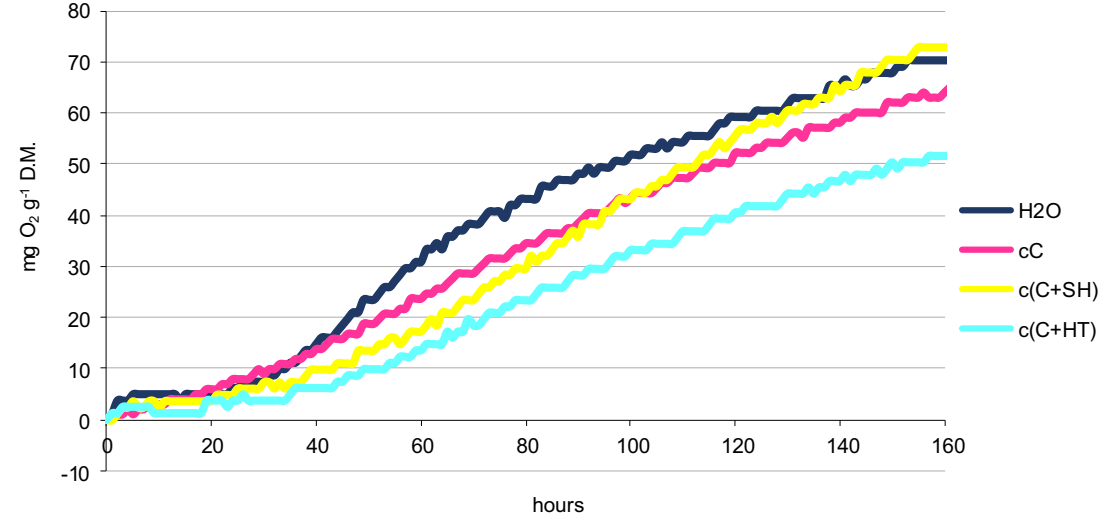

as equations in Table 3 (for $x=\mathrm{h}$ ). The periods were determined taking into account the course of recorded data, especially in the $\mathrm{S}+\mathrm{c}(\mathrm{C}+\mathrm{SH})$ treatment.

Comparing the direction coefficients (a) in the first incubation period (days 2-8), many times greater soil activity was found in compost-based treatments than in the control $(\mathrm{S})$. In the extreme case of $\mathrm{S}+\mathrm{c}(\mathrm{C}+\mathrm{SH})$, the activity was 28.8 times higher. In the second period analysed (days 9-17), soil responses measured with oxygen demand were more even in treatments with composts, but still several times higher in relation to the incubated soil $(\mathrm{S})$. The constant value of equation (b) determined from the 18th day in the $\mathrm{S}+\mathrm{cC}$ treatment was 20 times higher than the equation value for the incubated soil (S), as well as 90 times and 26 times higher, respectively, in treatments $\mathrm{S}+\mathrm{c}(\mathrm{C}+\mathrm{SH})$ and $\mathrm{S}+\mathrm{c}(\mathrm{C}+\mathrm{HT})$. This demonstrates a strong stimulation of microbiological processes in soil under the influence of composts and their high level caused by various hop sediments used in composting. During 28 days after introducing into the soil, HT compost $(\mathrm{S}+\mathrm{c}(\mathrm{C}+\mathrm{HT}))$ slowed down the respiratory processes in relation to the soil with a control compost based solely on maize $(\mathrm{S}+\mathrm{cC})$.

The tests carried out after soil incubation revealed that the number of microorganisms was very diverse and varied in soil depending on the compost added (Table 4). The largest number of vegetative bacteria $\left(10660 \times 10^{2} \mathrm{CFU} \mathrm{g}^{-1} \mathrm{DM}\right)$ was found in the soil with composted maize $(\mathrm{S}+\mathrm{cC})$. In addition, tests demonstrated that the number of vegetative bacteria in the $\mathrm{S}+\mathrm{c}(\mathrm{C}+\mathrm{SH})$ treatment $\left(2478 \times 10^{2} \mathrm{CFU} \mathrm{g}{ }^{-1} \mathrm{DM}\right)$ was nearly two times higher than in the $\mathrm{S}+\mathrm{c}(\mathrm{C}+\mathrm{HT})$ treatment $\left(1532 \times 10^{2} \mathrm{CFU} \mathrm{g}^{-1} \mathrm{DM}\right)$. An even greater difference in the soil enriched with hop sediment composts was found for endospore bacteria whose numbers were as follows: $112 \times 10^{2}$ $\mathrm{CFU} \mathrm{g}{ }^{-1} \mathrm{DM}(\mathrm{S}+\mathrm{c}(\mathrm{C}+\mathrm{SH}))$ and $6 \times 10^{2} \mathrm{CFU} \mathrm{g}^{-1} \mathrm{DM}(\mathrm{S}+$ $\mathrm{c}(\mathrm{C}+\mathrm{HT}))$. In the analysed soil, the greatest number of mould fungi was discovered in the $\mathrm{SH}$ compost treatment $(2877 \times$ $\left.10^{2} \mathrm{CFU} \mathrm{g}^{-1} \mathrm{DM}\right)$, while their level in the $\mathrm{S}+\mathrm{c}(\mathrm{C}+\mathrm{HT})$ amounted to $738 \times 10^{2} \mathrm{CFU} \mathrm{g}^{-1} \mathrm{DM}$. Actinomycetes were numerous in all treatments analysed, except for $\mathrm{S}+\mathrm{cC}$, and
Fig. 3 Respiratory activity during the incubation of composts with soil for a period of 28 days

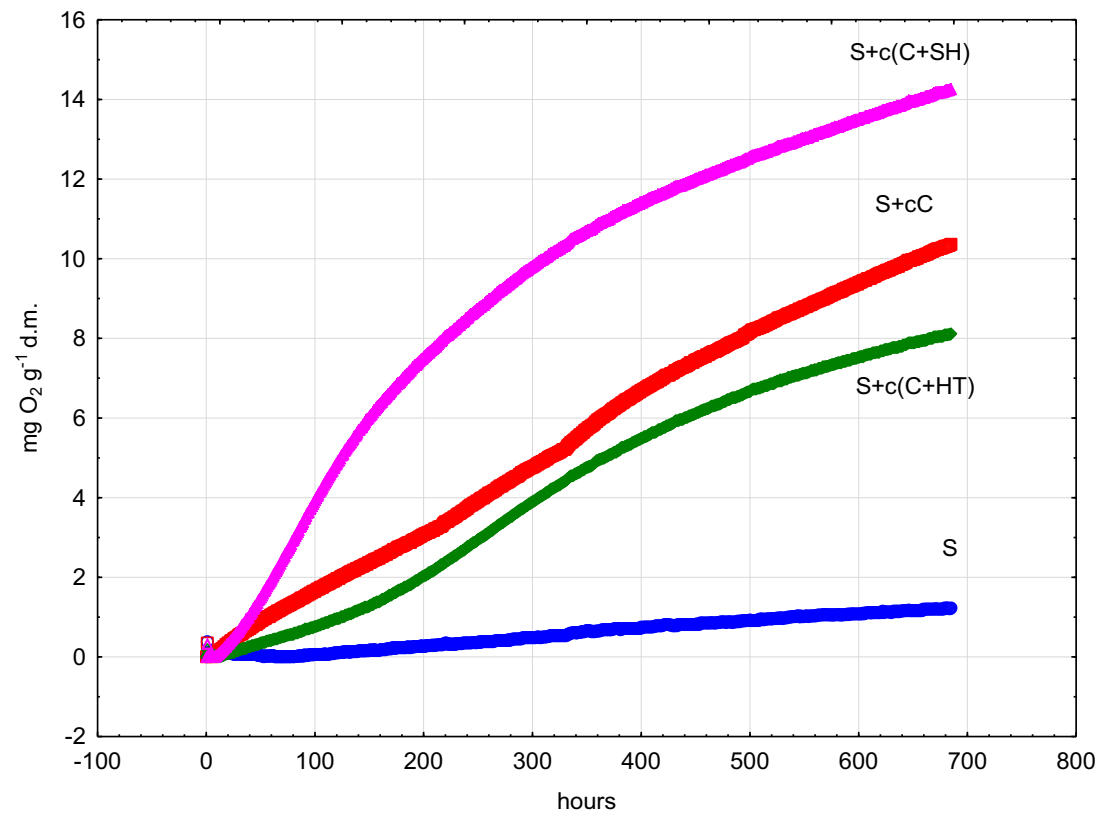


Table 3 Trend lines $(y=a x+b)$ of respiratory activity in three periods of soil incubation with composts

\begin{tabular}{|c|c|c|c|c|c|c|}
\hline \multirow[t]{2}{*}{ Treatment } & \multicolumn{6}{|l|}{ Period (h) } \\
\hline & $24-192$ & & $193-408$ & & $409-672$ & \\
\hline $\mathrm{S}$ & $y=0.0016 x-0.0563$ & $R^{2}=0.760$ & $y=0.0028 x-0.2663$ & $R^{2}=0.986$ & $y=0.002 x+0.0905$ & $R^{2}=0.990$ \\
\hline $\mathrm{S}+\mathrm{cC}$ & $y=0.0159 x+0.1761$ & $R^{2}=0.998$ & $y=0.0196 x-0.6761$ & $R^{2}=0.998$ & $y=0.0138 x+1.8680$ & $R^{2}=0.998$ \\
\hline $\mathrm{S}+\mathrm{c}(\mathrm{C}+\mathrm{HT})$ & $y=0.0110 x-0.2221$ & $R^{2}=0.988$ & $y=0.0190 x-1.5712$ & $R^{2}=0.997$ & $y=0.0096 x+2.3178$ & $R^{2}=0.989$ \\
\hline $\mathrm{S}+\mathrm{c}(\mathrm{C}+\mathrm{SH})$ & $y=0.0464 x-0.5429$ & $R^{2}=0.993$ & $y=0.0210 x+4.1682$ & $R^{2}=0.990$ & $y=0.0107 x+8.1877$ & $R^{2}=0.998$ \\
\hline $\mathrm{S}$ & \multicolumn{6}{|c|}{$y=0.002 x-0.0816 R^{2}=0.827$} \\
\hline $\mathrm{S}+\mathrm{cC}$ & \multicolumn{6}{|c|}{$y=0.0157 x+0.1034 R^{2}=0.9965$} \\
\hline $\mathrm{S}+\mathrm{c}(\mathrm{C}+\mathrm{HT})$ & \multicolumn{6}{|c|}{$y=0.0134 x-0.3355 R^{2}=0.9854$} \\
\hline $\mathrm{S}+\mathrm{c}(\mathrm{C}+\mathrm{SH})$ & \multicolumn{6}{|c|}{$y=5 \mathrm{E}-08 x^{3}-8 \mathrm{E}-05 x^{2}+0.0559 x-0.7959 R^{2}=0.9991$} \\
\hline
\end{tabular}

$R^{2}$, determination coefficient; $x=$ hour; range 24-192 h corresponds to days 2-8 of the incubation; range 193-408 $\mathrm{h}$ corresponds to days $9-17$ of the incubation; range 409-672 $\mathrm{h}$ corresponds to days 18-28 of the incubation

their values were from $3447 \times 10^{2} \mathrm{CFU} \mathrm{g}^{-1} \mathrm{DM}$ for the soil with no compost (S) to $7557 \times 10^{2} \mathrm{CFU} \mathrm{g}^{-1} \mathrm{DM}$ for $\mathrm{S}+\mathrm{c}(\mathrm{C}+$ $\mathrm{SH})$ ). The Azotobacter spp. the population was discovered in all treatments with the exception of $\mathrm{S}+\mathrm{cC}$, but it was not numerous. The largest number of Azotobacter spp., i.e. $0.7 \times 10^{2}$ $\mathrm{CFU} \mathrm{g}^{-1} \mathrm{DM}$, was discovered in the soil with composted $\mathrm{SH}$. The number of ammonifiers was also the highest in the sample of soil with the SH sediment $\left(753 \times 10^{2} \mathrm{CFU} \mathrm{g}^{-1} \mathrm{DM}\right)$, while in the sample with the $\mathrm{c}(\mathrm{C}+\mathrm{HT})$ compost, it amounted to 175 $\times 10^{2} \mathrm{CFU} \mathrm{g}^{-1} \mathrm{DM}$. Among all potentially pathogenic bacteria determined, only staphylococci were found with the highest number $\left(1105 \times 10^{2} \mathrm{CFU} \mathrm{g}{ }^{-1} \mathrm{DM}\right)$ in the soil with composted maize $(\mathrm{S}+\mathrm{cC})$. The soil sample containing $\mathrm{c}(\mathrm{C}+$

Table 4 Average number of microorganisms $\left(10^{2} \mathrm{CFU} \mathrm{g}{ }^{-1} \mathrm{DM}\right)$ and the nitrogen cycle bacteria titres in the soil incubated with composts against $\mathrm{pH}$ and $\mathrm{EC}$

\begin{tabular}{lllll}
\hline Microorganisms & \multicolumn{2}{l}{ Treatment } \\
\cline { 2 - 5 } & $\mathrm{S}$ & $\mathrm{S}+\mathrm{cC}$ & $\mathrm{S}+\mathrm{c}(\mathrm{C}+\mathrm{HT})$ & $\mathrm{S}+\mathrm{c}(\mathrm{C}+\mathrm{SH})$ \\
\hline Vegetative bacteria & 3120 & 10660 & 1532 & 2478 \\
Bacterial endospores & 4 & 80 & 6 & 112 \\
Mould fungi & 457 & 543 & 738 & 2877 \\
Actinobacteria & 3447 & 0 & 5420 & 7557 \\
Azotobacter spp. & 0.6 & 0 & 0.1 & 0.7 \\
Ammonifiers & 75 & 203 & 175 & 753 \\
Nitrifiers & $10^{-3}$ & $10^{-1}$ & $10^{-3}$ & $10^{-4}$ \\
Denitrifiers & $10^{-2}$ & $10^{-1}$ & $10^{-4}$ & $10^{-5}$ \\
C. pasteurianum & $10^{-2}$ & $10^{-2}$ & $10^{-2}$ & $10^{-2}$ \\
Staphylococci & 262 & 1105 & 71 & 110 \\
Soil properties & & & & \\
pH H $\mathrm{H}_{2} \mathrm{O}$ & 4.37 & 5.87 & 4.93 & 5.39 \\
pH KCl & 4.12 & 5.80 & 4.87 & 5.36 \\
EC (mS/cm) & 3.84 & 5.68 & 4.79 & 5.31 \\
\hline
\end{tabular}

SH) was more numerously inhabited by Staphylococcus spp. $\left(110 \times 10^{2} \mathrm{CFU} \mathrm{g}^{-1} \mathrm{DM}\right)$ than $\mathrm{c}(\mathrm{C}+\mathrm{HT})\left(71 \times 10^{2} \mathrm{CFU} \mathrm{g} \mathrm{g}^{-1}\right.$ $\mathrm{DM}$ ), but hop sediment composts clearly inhibited the growth of these microorganisms. Table 4 does not contain results regarding the number of Escherichia coli, Enterococcus faecalis, Clostridium perfringens, Salmonella spp. and Shigella spp. since these microorganisms were not found in the analysed samples. The tested samples' $\mathrm{pH}$ ranged from 4.37 to 5.87 , thus oscillating within the acidic $\mathrm{pH}$, preferred by fungi as opposed to bacteria for which neutral $\mathrm{pH}$ is considered optimal [17]. However, due to the fact that a mixed population of microorganisms was found in the tested samples, this effect is not so clear. Therefore, the number of microorganisms analysed cannot be attributed to the $\mathrm{pH}$. The titre of nitrifiers and denitrifiers ranged, depending on the sample, from $10^{-1}$ to $10^{-5}$. The sample amended with $\mathrm{c}(\mathrm{C}+$ $\mathrm{SH})$ had a higher titre of nitrifiers and denitrifiers than the sample with $\mathrm{c}(\mathrm{C}+\mathrm{HT})$. In contrast, the titre of C. pasteurianum was $10^{-2}$ in all samples.

Although the composting of hop sediments from brewing is described in the literature [7,23], there are only few reports on the practical use of this method in the utilisation of this postprocess waste. That is why the presented studies may contribute to a better understanding and optimisation of the method of using brewing sediments. In the study of Kopeć et al. [16], in which, among others, maize straw, coffee grounds and sewage sludge were composted, a much higher number of bacteria was discovered compared with the present study, and it ranged from $33.2 \times 10^{6} \mathrm{CFU} \mathrm{g}^{-1} \mathrm{DM}$ to $183.0 \times 10^{6} \mathrm{CFU} \mathrm{g}^{-1} \mathrm{DM}$. The numbers of other microorganisms analysed by Kopeć et al. [16] were as follows: mould fungi from $168.9 \times 10^{3} \mathrm{CFU} \mathrm{g}^{-1} \mathrm{DM}$ to $819.1 \times 10^{3} \mathrm{CFU} \mathrm{g}^{-1} \mathrm{DM}$, coliforms and $E$. coli from $<3 \mathrm{CFU}$

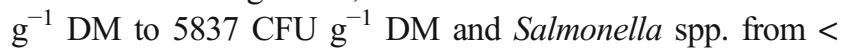
$3 \mathrm{CFU} \mathrm{g}{ }^{-1}$ DM to $251 \mathrm{CFU} \mathrm{g}^{-1} \mathrm{DM}$. Such a high number of bacteria and mould fungi compared with the present results is probably caused by the type of composted material. Kopeć 
et al. [16] applied sewage sludge which is a source of many microorganisms, including those potentially pathogenic (Shchegolkova et al. [24]). Similarly higher numbers of microorganisms, including pathogens, were found by Malinowski et al. [20] in composted biowaste with the addition of biochar. Depending on the process day, the number of bacteria, fungi and Actinomycetes was even $5250 \times 10^{4} \mathrm{CFU} \mathrm{g}^{-1} \mathrm{DM}, 26.7 \times$ $10^{4} \mathrm{CFU} \mathrm{g}^{-1} \mathrm{DM}$ and $19.5 \times 10^{4} \mathrm{CFU} \mathrm{g}^{-1} \mathrm{DM}$, respectively. The presence of microorganisms that pose a threat from an epidemiological point of view was also determined, i.e. E. coli $\left(67.4 \times 10^{4} \mathrm{CFU} \mathrm{g}^{-1} \mathrm{DM}\right)$, Salmonella spp. $\left(6.2 \times 10^{4}\right.$ $\left.\mathrm{CFU} \mathrm{g}{ }^{-1} \mathrm{DM}\right)$ and Staphylococcus spp. $\left(145.6 \times 10^{4} \mathrm{CFU} \mathrm{g}^{-1}\right.$ DM). Mierzwa-Hersztek et al. [25] showed that the fertilisation of soil with composts amended with biochar from a thermally transformed wheat straw can be an excellent way of managing waste agricultural biomass. Based on their study, the authors concluded that the application of biochar significantly improves soil quality and affects the number and composition of the microbial population inhabiting it. In the analysed soil with the addition of composted materials, Mierzwa-Hersztek et al. [25] found even $2404 \times 10^{3} \mathrm{CFU} \mathrm{g}^{-1} \mathrm{DM}$ and $88 \times 10^{3} \mathrm{CFU}$ $\mathrm{g}^{-1} \mathrm{DM}$ of vegetative bacteria and mould fungi, respectively. Depending on the analysed sample, Actinomycetes and ammonifiers were numerous $\left(25 \times 10^{3} \mathrm{CFU} \mathrm{g}{ }^{-1} \mathrm{DM}, 862 \times\right.$ $\left.10^{3} \mathrm{CFU} \mathrm{g}^{-1} \mathrm{DM}\right)$ or were not determined. The titre of nitrifiers and denitrifiers ranged, depending on the sample, from $10^{-2}$ to $10^{-6}$. In contrast, the titre of $C$. pasteurianum was $10^{-2}$ or $10^{-3}$.

There is no information in the literature on the microbiological aspects of introducing hop sediments into the soil. The effect of this waste on soil properties is explained only in the context of hop being grown under field conditions. In molecular studies of soil microorganisms [26] in conventional and ecological hop production systems (in the same soil and climate), seasonal variations and fluctuations in the microbiological state of soil were found. These studies made no significant differences in the number of hop crops. Oszust et al. [26] explained this by the beneficial effect of organic production on the microbiological activity of the soil, resulting from the application of natural fertilisers. In the case of composts, hop sediments also share a small proportion of other biomass.

Due to the feedstock used in the preparation of beer, hop sediments are a complex matrix of organic compounds, which, under composting conditions, undergo changes conditioning their toxicity. The different effects of sequentially extracted compounds from hops on microorganisms demonstrated by Jeliazkova et al. [27] will also characterise composts. The time of organic compound oxidation and processes occurring during composting, as well as subsequent changes in soil, should help reduce the level of inhibited microbiological changes. In the context of plant nutrient management, it is important to know the rate and level of activity of compounds inhibiting biological and chemical processes. The study should be continued, as it gives hope for obtaining composts having characteristics relevant to the protection of plants against pathogens. This approach could contribute to supplementing the fertiliser value of obtained composts in hygienising properties against plant pathogens.

\section{Summary}

The microbiological analysis of composted hop sediments made in this study allowed to demonstrate a large variety of microorganisms inhabiting the tested feedstocks, while at the same time, lacking potentially pathogenic microorganisms. On this basis, it can be concluded that the tested material does not pose a threat from an epidemiological point of view. In addition, the study revealed that the number of microorganisms analysed in the soil after incubation with compost based on spent hops ( $\mathrm{SH})$ from dry hopping was significantly higher than that determined in soil with compost containing hot trub (HT) from wet hopping. The results of microbiological analyses correspond to the results of physicochemical analyses, giving the basis for considering the SH sediment a more useful material for composting.

This situation is probably caused by the nature of dry and wet hopping (differences in processing and use of sediments in the brewery and different process temperature) and its course, which had a large impact on the analysed parameters of composted sediments.

The study confirmed the inhibitory properties of composts obtained from hop sediments from wet brewing. These properties characteristic to HT hop sediments persist after the biological aerobic transformation. This does not exclude their use in the composting process; however, it requires further studies determining the share of HT in feedstocks used in composting and the time of transformation taking place in the soil. The choice of compost application technology can have an effect on the final fertiliser value of HT-based composts. Under certain meteorological conditions, it may be useful to use plant growth retarder offered by the HT-based compost. Despite the temporary inhibition of plant growth in the presence of HT, this material should not be eliminated from composts, because it has fertilising potential.

Funding information This work was financially supported by Grant LIDER 46/0185/L-9/17/NCBR/2018.

Open Access This article is licensed under a Creative Commons Attribution 4.0 International License, which permits use, sharing, adaptation, distribution and reproduction in any medium or format, as long as you give appropriate credit to the original author(s) and the source, provide a link to the Creative Commons licence, and indicate if changes were made. The images or other third party material in this article are included in the article's Creative Commons licence, unless indicated otherwise in a credit line to the material. If material is not included in the article's Creative Commons licence and your intended use is not permitted by 
statutory regulation or exceeds the permitted use, you will need to obtain permission directly from the copyright holder. To view a copy of this licence, visit http://creativecommons.org/licenses/by/4.0/.

\section{References}

1. Schisler DO, Ruocco JJ, Mabee MS (1982) Wort trub content and its effects on fermentation and beer flavor. J Amer Soc Brew Chem 40(2):57-61

2. Mathias TRDS, de Mello PPM, Sérvulo EFC (2014) Solid wastes in brewing process: a review. J Brew Distill 5(1):1-9

3. Oladokun O, James S, Cowley T, Smart K, Hort J, Cook D (2017) Dry-hopping: the effects of temperature and hop variety on the bittering profiles and properties of resultant beers. Brew Sci 70: 187-196

4. Sterczyńska M, Stachnik M (2017) Technical and technological aspects of clarification of beer wort. Food Proc Eng 4:24-27

5. Sterczyńska M, Stachnik M, Poreda A, Jakubowski M (2018) Hot trub - by product of production of clarified beer wort. Food Proc Eng 2:36-41

6. Guidelines on the use of by-products and the recommended waste management in agriculture and the agri-food industry (2010) Ministry of Agriculture and Rural Development, Falenty Warsaw Institute of Technology and Life Sciences, Warsaw, November 2010, pp. 103.

7. Stocks C, Barker AJ, Guy S (2002) The composting of brewery sludge. J Inst Brew 108:452-458

8. Fărcaş AC, Socaci SA, Mudura E, DulfFV, Vodnar DC, Tofană M, Salanță LC (2017) Exploitation of brewing industry wastes to produce functional ingredients. Brewing Technol:137-156

9. Kerby C, Vriesekoop F (2017) An overview of the utilisation of brewery by-products as generated by british craft breweries. Beverages 3(2):1-12

10. Flythe MD, Aiken GE (2010) Effects of hops (Humulus lupulus L.) extract on volatile fatty acid production by rumen bacteria. J Appl Microbiol 109(4):1169-1176

11. Flythe MD, Kagan IA, Wang Y, Narvaez N (2017) Hops (Humulus lupulus L.) bitter acids: modulation of rumen fermentation and potential as an alternative growth promoter. Front Vet Sci 4:1-14

12. Jeliazkova E, Zheljazkov VD, Kačániova M, Astatkie T, Tekwani BL (2018) Sequential elution of essential oil constituents during steam distillation of hops (Humulus lupulus L.) and influence on oil yield and antimicrobial activity. J Oleo Sci 67(7):871-883

13. Bedini S, Flamini G, Girardi J, Cosci F, Conti B (2015) Not just for beer: evaluation of spent hops (Humulus lupulus L.) as a source of eco-friendly repellents for insect pests of stored foods. J Pest Sci 88(3):583-592
14. Zanoli P, Zavatti M (2008) Pharmacognostic and pharmacological profile of Humulus lupulus L. J Ethnopharmacol 116(3):383-396

15. Kopeć M, Mierzwa-Hersztek M, Gondek K, Wolny-Koładka K, Zdaniewicz M (2020) The application potential of hop sediments from beer production for composting Saudi J Biol Sci (in press).

16. Kopeć M, Baran A, Mierzwa-Hersztek M, Gondek K, Chmiel MJ (2018) Effect of the addition of biochar and coffee grounds on the biological properties and ecotoxicity of composts. Waste Biom Valor 9(8):1389-1398

17. Malinowski M, Wolny-Koładka K (2017) Microbiological and energetic assessment of the effects of the biodrying of fuel produced from waste. Ecol Chem Eng S 24(4):551-564

18. Atlas RM, Parks LC (1997) Handbook of microbiological media, 2nd edn. CRC Press, Boca Raton, p 1706

19. Wolny-Koładka K, Żukowski W (2017) Mixed municipal solid waste hygienisation for refuse-derived fuel production by ozonation in the novel configuration using fluidized bed and horizontal reactor. Waste Biom Val 10:575-583

20. Malinowski M, Wolny-Koładka K, Vaverková MD (2019) Effect of biochar addition on the OFMSW composting process under real conditions. Waste Manag 84:364-372

21. Mathias TRDS, Alexandre VMF, Cammarota MC, de Mello PPM, Sérvulo EFC (2015) Characterization and determination of brewer's solid wastes composition. J Inst Brew 121(3):400-404

22. Poreda A, Stefaniuk K, Hoc J, Zdaniewicz M (2014) Improved efficiency of brewers wort supplementation with zinc ions. Ferment Fruit Veget Ind 2(58):4-8

23. Thomas KR, Rahman PKSM (2006) Brewery wastes. Strategies for sustainability. A review. Asp Appl Biol 80:147-153

24. Shchegolkova NM, Krasnov GS, Belova AA (2016) Microbial community structure of activated sludge in treatment plants with different wastewater compositions. Front Microbiol 7(90):1-15

25. Mierzwa-Hersztek M, Wolny-Koładka K, Gondek K, Gałązka A, Gawryjołek K (2019) Effect of coapplication of biochar and nutrients on microbiocenotic composition, dehydrogenase activity index and chemical properties of sandy soil. Waste Biom Val. https://doi. org/10.1007/s12649-019-00757-z

26. Oszust K, Frac M, Gryta A, Bilińska N (2014) The influence of ecological and conventional plant production systems on soil microbial quality under hops (Humulus lupulus). Int J Mol Sci 15(6): 9907-9923

27. Jeliazkova E, Zheljazkov VD, Kačániova M., Astatkie T, Tekwani BL 2018, Sequential elution of essential oil constituents during steam distillation of hops (Humulus lupulus L.) and influence on oil yield and antimicrobial activity. J. Oleo Sci. http://www.jstage. jst.go.jp/browse/jos/

Publisher's Note Springer Nature remains neutral with regard to jurisdictional claims in published maps and institutional affiliations. 